\title{
Russian Amino Chelate Fertilizers of Agrovin Type Applied on White Cabbage
}

\author{
M S Gaplaev1, M II Ivanova², A N Nehoroshev³, and S B Erlykov \\ ${ }^{1}$ Chechen Agricultural Research Institute, Grozny, Russia \\ ${ }^{2}$ Federal Research Centre for the Horticulture of Vegetables \\ ${ }^{3}$ Agrooptima LLC, Korolyov, Moscow region, Russia \\ ${ }^{4}$ CEO of Agrooptima LLC. Korolyov, Russia
}

Corresponding Author:

M S Gaplaev

gaplaev63@list.ru

Received: 25 October 2019

Accepted: 15 November 2019

Published: 25 November 2019

Publishing services provided by Knowledge E

(c) M S Gaplaev et al. This article is distributed under the terms of the Creative Commons

Attribution License, which permits unrestricted use and redistribution provided that the original author and source are credited.

Selection and Peer-review under the responsibility of the AgroSMART 2019 Conference Committee.

\section{Abstract}

When applying synthetic chelate fertilizers, the plant "takes away" only the element of nutrition, and the chelator (as a foreign element, ballast) gets into the soil, where over time, accumulating, creates negative environmental consequences. The use of amino acids in foliar fertilizers is one of the most promising ways to eliminate the impact of harmful environmental conditions on agricultural plants. In addition, consumers have recently been very interested in organic food and have been demanding quality and food safety. Translocation of amino acids takes place both in the phloem and in the xylem, which helps to dispose of nitrogen in the roots and above-ground part of the plant and accelerates the retransmission of nutrients in plants, in particular, fixed elements. The absorption rate of amino acids depends on the biological characteristics of the plants and the characteristics of the amino acids. The research is aimed at determining the influence of leaf fertilizing with amino chelate fertilizers of the Agrovin series on the growth, development and yield of white cabbage.

Keywords: amino chelate fertilizer, foliar feeding, white cabbage, plant growth and development, yield.

\section{Introduction}

In the context of intensive crop cultivation technologies, the role of strict compliance with agrotechnical requirements and environmental restrictions is increasing. A high level of agricultural machinery, from tillage to harvesting, is a prerequisite for efficient fertilizer use $[1,5]$.

Taking into account the high demand of plants for balanced nutrition during the critical period of development and the complexity of assimilation of the necessary elements of the root system in this period, even if they are present in the soil, special importance is given to foliar feeding with special water-soluble fertilizer complexes with microelements. Foliar feeding is most effective when soil has a low nutrient level, the 
upper layer of soil is dry, and root activity during the reproductive period decreases $[2,3,26]$.

Micronutrients are of fundamental importance for plant growth and development, acting as components of cell walls (B) and membranes (B and $\mathrm{Zn}$ ), as components of enzymes (Fe, Mn, $\mathrm{Cu}$ and $\mathrm{Ni}$ ) and their activation ( $\mathrm{Mn}$ and $\mathrm{Zn}$ ), as well as participating in photosynthesis ( $\mathrm{Fe}, \mathrm{Cu}, \mathrm{Mn}$ and $\mathrm{Cl}$ ). For foliar feeding, it is essential to deliver nutrients to plants with a low risk of phytotoxicity $[6,17,23]$.

When amino acids are used in foliar fertilizers together with microelements, nutrients are absorbed and transported by plants much faster. Amino acids, as natural chelating agents in the soil-plant system, have the ability to coordinate metal ions through their carboxylic groups and thus increase their availability for plants [7, 12--14, 20, 27].

Amino acid and peptide mixtures are obtained by chemical and enzymatic hydrolysis of protein from agricultural by-products: plant residues and animal wastes (e.g. collagen, epithelial tissues) $[9,10,15,22]$.

Therefore, this study was conducted in order to assess the influence of amino chelate fertilizers of the Agrooptim type produced by LLC "Agrooptima" on the growth, development and yield of white cabbage Forsage F1.

\section{Methods and Materials}

Factors under study: 1) types of fertilizers: Agrovin Universal (0,7; 1,0 and 1,3 kg/ha), Agrovin Amino (0,2; 0,4; 0,6 l/ha), Agrovin Micro (0,4;0,6 and 0,8 l/ha); 2) multiplicity of feeding: the first one -- in the phase of 5--7 leaves; the second one -- in the phase of the beginning of the formation of sprouts. Control plants were sprayed with distilled water.

The composition of amino chelate fertilizers includes a mixture of 18 amino acids AA80. Raw material for production of amino acids is vegetable (soybean, grain crops).

Characteristics of amino chelate fertilizers of the Agrovin series produced by LLC "Agrooptima" are presented in Table 1.

The previous one is tomato. On the background -- $\mathrm{N}_{180} \mathrm{P}_{80} \mathrm{~K}_{240}$. Plantation of seedlings $70 \times 50 \mathrm{~cm}$. Density -- 28570 plants/ha. The area of the record plot is $15 \mathrm{~m}^{2}$. Each variant is placed in 2 rows, between variants -- 1 protective row. Repetition is fourfold. Agrotechnics is common for the low-frequency zone. 
TABLE 1: Characteristics of amino chelate fertilizers.

\begin{tabular}{|c|c|c|c|c|c|c|c|c|c|c|}
\hline \multirow{2}{*}{$\begin{array}{l}\text { Name } \\
\text { (pharmaceutical } \\
\text { form) }\end{array}$} & \multicolumn{10}{|c|}{ Element content, \% } \\
\hline & $\begin{array}{l}\text { amino } \\
\text { acids }\end{array}$ & $\mathrm{Fe}$ & $\mathrm{Cu}$ & Zn & Mn & Mg & B & $\mathbf{N}$ & $\mathbf{K}$ & $\mathbf{S}$ \\
\hline Agrovin Micro (G) & 6.0 & 0.75 & 0.25 & 0.75 & 0.25 & 1.2 & 0.2 & 1.0 & 0.1 & -- \\
\hline Agrovin Amino (G) & 26.6 & -- & -- & -- & -- & -- & -- & 4.2 & -- & -- \\
\hline $\begin{array}{l}\text { Agrovin Universal } \\
\text { (KRP) }\end{array}$ & 1.0 & 0.15 & 0.05 & 0.1 & 6.2 & 2.2 & 6.5 & -- & 0.02 & 7.2 \\
\hline
\end{tabular}

Evaluation of plant infestation by vascular bacteriosis was carried out according to the method of O.V. Studentsov, N.N. Petrovskaya [4], and clubroot of crucifers -- according to the method of S. Buczacki [8].

Statistical processing of experimental data was carried out using Microsoft Excel software package.

Weather conditions of the growing seasons of 2015 and 2016 were generally favorable for the growth and development of white cabbage plants.

Soil of the pilot plot is medium loamy, cultivated, moisture-intensive, depth of arable layer is $27 \mathrm{~cm}$, groundwater depth is more than $2.0 \mathrm{~m}$. Volumetric mass of the top layer $--1,1 \ldots 1,2 \mathrm{t} / \mathrm{m}^{3}$, underlying layers $--1,2 \ldots 1,3 \mathrm{t} / \mathrm{m}^{3}$. Density of soil solid phase (specific mass) -- 2,58...2,60 t/m $\mathrm{m}^{3}$. Soil water content is optimal for agricultural crops, varies in layers from 52.1 to $55.0 \%$. Soil has a high level of natural fertility, $\mathrm{pH}$ of salt 5.5...6.1, humus content in the arable layer varies from 3.5 to $3.8 \%$, total nitrogen -- from 0.19 to $0.24 \%$, nitrate nitrogen -- from 2.0 to $2.8 \mathrm{mg} / 100 \mathrm{~g}$, the content of phosphorus in the soil -- 17.6...19.1 mg/100 g, potassium supply -- 7.0...8.2 mg/100 g. Hydrolytic acidity

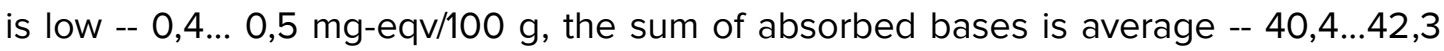
mg-eqv/100 g, the degree of saturation of soil with bases is high -- 98,8...99,1\%. The lowest soil moisture capacity (LW) is $30 \%$. These data allow to classify the soil of the experimental site as sufficiently fertile and suitable for growing white cabbage.

\section{Results}

White cabbage is quite demanding to the fertility of the soil, well responds to the application of fertilizers. Late varieties of cabbage consume up to $10 \mathrm{~kg} / \mathrm{ha}$ of nitrogen per day during the formation phase of the cabbage. The maximum absorption of potassium (up to $9 \mathrm{~kg} / \mathrm{ha}$ ) and phosphorus (up to $3.5 \mathrm{~kg} / \mathrm{ha}$ ) occurs at a later date - the period of maturation of the sprout. For early varieties of cabbage, the maximum 
absorption of nutrients (up to $8 \mathrm{~kg} / \mathrm{ha}$ of nitrogen, 4.1 potassium, and 1.7 phosphorus per day) also falls on the phase of intensive formation of cabbage [1].

In the Central district on alluvial meadow medium loamy soils it is recommended to grow late varieties and hybrids of cabbage of white cabbage at regular irrigation with differentiated level and depth of soil moisture (70; 80; 70 \% HB and 30; 40; 40; $40 \mathrm{~cm}$; $1 . . .3$ watering) on the background of two fertilizers ( $\mathrm{N} 50$ и K50) or on the background of N180P80K240 [1].

The analysis of the results of the trial digestion (July 25--26) showed that in the control version -- without fertilizing -- the weight of the decumbent crown was 687.5 $\mathrm{g} /$ plant, the weight of the root system -- $84.5 \mathrm{~g} / \mathrm{plant}$, the diameter of the sprout is 9.5 $\mathrm{cm}$, the weight of the sprout is $361.5 \mathrm{~g}$. The plant infestation with vascular bacteriosis is 1.5 points, and with a keel -- 3.0 points (Table 1).

Agrovin Universal: the maximum weight of the decumbent crown was in the variant of the norm of $0.7 \mathrm{~kg} / \mathrm{ha}--1016.5 \mathrm{~g}$, the minimum -- at the norm of $1.0 \mathrm{~kg} / \mathrm{ha} \mathrm{--} 943.5 \mathrm{~g}$ against $687.5 \mathrm{~g}$ in control. The number of leaves decreased from 17.8 to $15.1 \mathrm{pcs} / \mathrm{plant}$ with the increased rate of consumption of the preparation at $18.4 \mathrm{pcs} /$ plant in the control version. At a one-time foliar feeding with the Agrovin Universal at the rate of $1.3 \mathrm{~kg} / \mathrm{ha}$ there was established a low affection of white cabbage plants with vascular bacteriosis -- 0.2 points. No clubroot-affected plants. The mass of the root system was $80.5 \mathrm{~g}$. It was found out that with the increase of the norm of the substance consumption the infestation of plants with vascular bacteriosis decreases (from 0.6 to 0.2 points). Agrovin Universal with a norm of $1.3 \mathrm{~kg} / \mathrm{ha}$ contributed to the formation of the mass of the cabbage $787.5 \mathrm{~g}$. The diameter of the sprout was $12.4 \mathrm{~cm}$. It was found out that with the increase of the rate of consumption of the preparation, the weight of the male herd increases, but the content of dry substances in the male herd decreases from 7.54 to $6.77 \%$.

Amino Agrovin with a rate of $0.2 \mathrm{l} / \mathrm{ha}$ contributed to the formation of the maximum mass of the decumbent crown $(12650 \mathrm{~g})$, with the number of leaves in the outlet was $12.7 \mathrm{pcs}$. At a rate of $0.6 \mathrm{l} / \mathrm{ha}$ these figures were at the level of $966.5 \mathrm{~g}$ and $17.9 \mathrm{pcs}$., at a rate of $0.4 \mathrm{l} / \mathrm{ha}--894.5 \mathrm{~g}$ and $16.7 \mathrm{pcs}$. respectively. When using Amino Agrovin with the norm of $0.2 \mathrm{l} / \mathrm{ha}$, the mass of the root system was $98.5 \mathrm{~g}$, the infestation of plants with vascular bacteriosis was 0.4 points, and with a clubroot -- 0.1 point.

There was an increase in plant infestation by vascular bacteriosis with an increase in the rate of consumption of the preparation -- from 0.4 to 0.8 points. Infestation of plants with clubroot was $0.1 \ldots 0.2$ points against 3 points in the control variant. The largest weight of the cabbage was formed with the use of Amino Agrovin in the norm of 0.2 
I/ha: the diameter of the cabbage $-12.8 \mathrm{~cm}$, weight $-796.0 \mathrm{~g}$. The content of dry substances in the cabbage was $7.56 \%$. The maximum values of decumbent crown and root system mass are noted.

Agrovin Micro at a rate of $0.6 \mathrm{l} / \mathrm{ha}$ contributed to the formation of the largest mass of decumbent crown (1133.0 g) due to the maximum number of leaves (19.3 pcs.). Минимальная пораженность растений сосудистым бактериозом (0,1 балл) отмечена В Варианте АгроВин Микро 0,8 л/га. This indicator was 1.5 points during the control. With the increase in the rate of consumption of agrochemicals there was a decrease in plant infestation by vascular bacteriosis from 0.3 to 0.1 points. There are no lesions of clubroot of crucifers (0 points) in all variants of application of Agrovin Micro. Agrovin Micro with $0.6 \mathrm{I} /$ ha norm of flow: the largest mass of the sprout was formed $(822.5 \mathrm{~g})$ due to the formation of the maximum number of leaves in the decumbent crown $(19.3 \mathrm{~cm})$, the mass of the decumbent crown leaves $(1133.0 \mathrm{~g} / \mathrm{plant})$, the mass of the root system (89.0 $\mathrm{g} /$ plant). The increase in leaf size is due to better development of the root system and increased translocation of carbohydrates from the source to the growing roots [19, 24]. Available micronutrients have helped to increase the number of leaves, resulting in higher photoassimilation and accumulation of dry matter. These results are confirmed by the conclusions of foreign scientists $[25,28]$.

The harvesting of cabbage was carried out on August 20--22. The structure of harvest and yield of cabbage of white cabbage Forsage F1 depending on the foliar application with amino chelate fertilizers of Agrovin series are presented in Table 2.

Agrovin-Universal: Maximum yield of white cabbage Fast-forward F1 (82.9 t/ha) was obtained at double feeding with Agrovin Universal $0.7 \mathrm{~kg} / \mathrm{h}$ a due to the formation of the largest mass of cabbage $(2.9 \mathrm{~kg})$. The diameter of the sprout was $20.5 \mathrm{~cm}$. The increase in the commercial yield to the control was $70.6 \%$ in relation to the control variant.

Agrovin Micro 0.6 I/ha: the yield was $68.6 \mathrm{t} / \mathrm{h}$, the weight of cabbage -- $2.4 \mathrm{~kg}$. The increase in commercial yields amounted to $41.2 \%$ to control. At the rate of consumption of $0.4 \mathrm{l} /$ ha the increase in the commercial yield was $14.3 \mathrm{t} / \mathrm{ha}$ to the control, at the rate of consumption of $0.8 \mathrm{l} / \mathrm{ha}$ the yield was at the level of the control variant.

Agrovin Amino contributed to the formation of the yield of the cabbage at the level of $71.4 \mathrm{t} / \mathrm{ha}$. In this case, the weight of the cabbage was $2.5 \mathrm{~kg}$. The increase in commercial yields amounted to $46.9 \%$ to control. In this case, the maximum content of vitamin $\mathrm{C}$ in the sprout is $25.8 \mathrm{mg} / 100 \mathrm{~g}$. The decrease in the yield of cabbage with the increase in the rate of consumption of the product -- from 71.4 to $57.1 \mathrm{t} /$ ha was noted.

Therefore, to form the yield of cabbage with white cabbage at the level of $71 \ldots 82 \mathrm{t} / \mathrm{ha}$ double fertilizing with small rate of consumption of agrochemicals is enough: Agrovin 


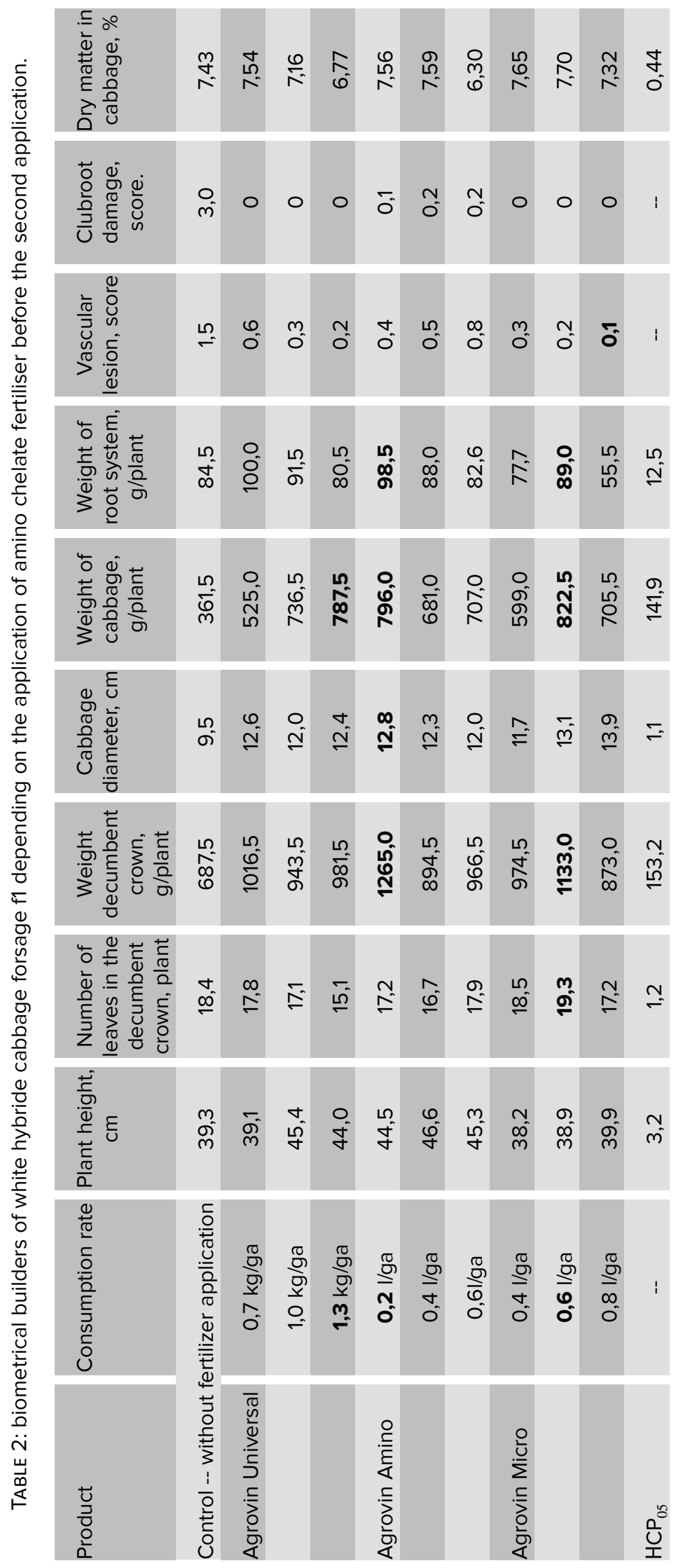




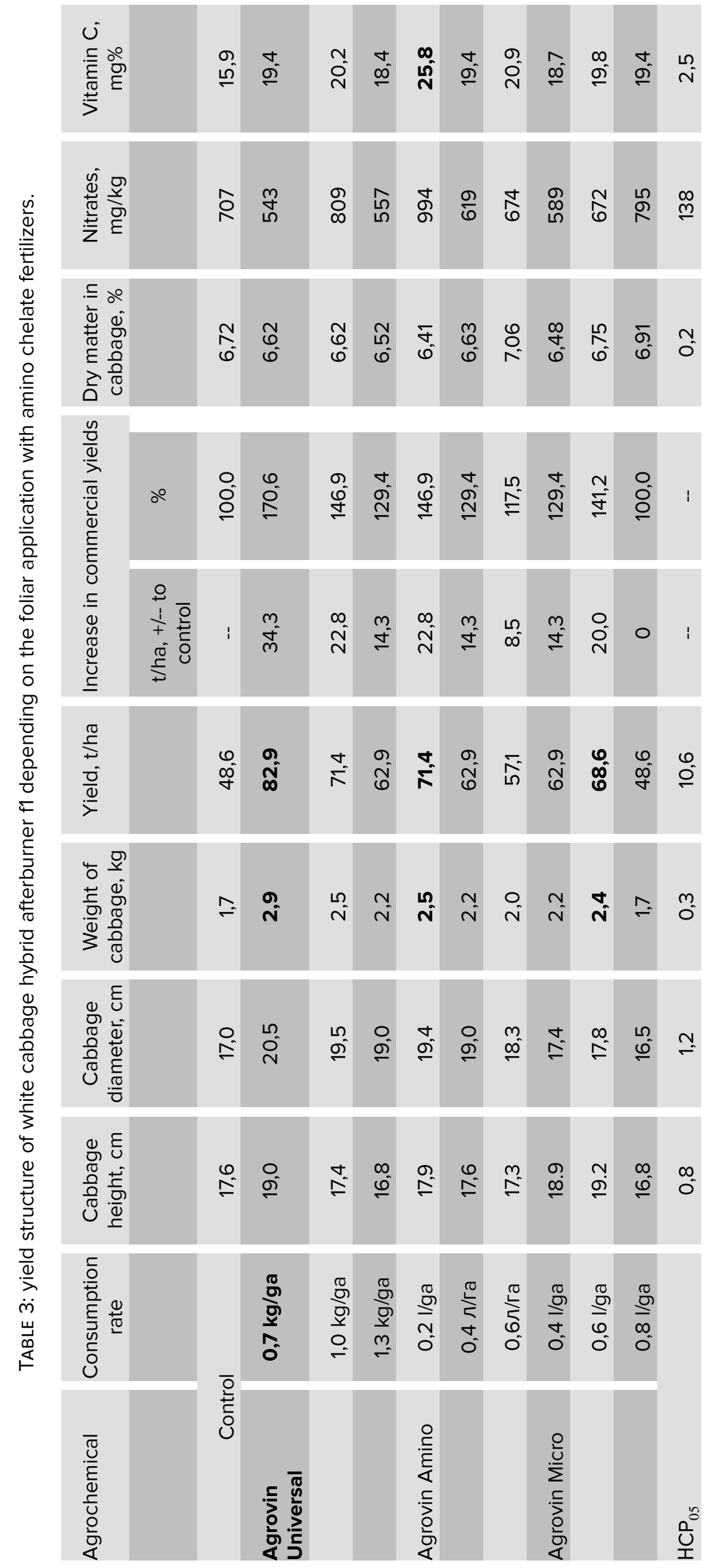


Universal $0.7 \mathrm{~kg} / \mathrm{ha}$ and Agrovin Micro $0.2 \mathrm{l} / \mathrm{h}$. Amino acids may have contributed to the uptake of micronutrients and also served as a source of nitrogen for optimal plant growth and development, which in turn minimized crop losses due to disease. The results of our studies are consistent with the conclusions of international researchers [11, 16--18, 21].

Comparison of the dry matter content in cabbage at different times shows that the dry matter content of cabbage was significantly higher than at the time of harvesting. This is related to the consumption of solids by plants to produce an increase in the weight of the cabbage.

The maximum permissible concentration of nitrates in cabbage heads is $900 \mathrm{~g} / \mathrm{kg}$. Only in the variant of Agrovin Amino $0.2 \mathrm{l} /$ ha the maximum permissible concentration of MPCs is exceeded by $94 \mathrm{mg} / \mathrm{kg}$.

\section{Conclusion}

On alluvial meadow soils of the non-chernozem zone for the formation of average ripe white cabbage yield at the level of $82.9 \mathrm{t} /$ ha against the background of N180P80K240 double fertilizing with $0.7 \mathrm{~kg} / \mathrm{ha}$ of Agrovin Universal is effective, which is $34.3 \mathrm{t} / \mathrm{ha}$ higher compared to the control and 11.5 t/ha compared to Amino Agrovin 0.2 I/ha. The first fertilization should be carried out in phase $5 . . .7$ leaves, the second -- in the phase of the beginning of the formation of sprouts. Agrovin products increase the resistance of plants to stress and disease, thereby increasing the yield of commercial products and the yield of white cabbage.

\section{References}

[1] Borisov, V.A. (2016). Vegetable Crop Fertilizer System. Moscow: Rosinformagrotech, $392 \mathrm{p}$.

[2] Edemskaya, N.L., Lebedeva, L.A., Arzamazov, A.V. (2010). Scientific principles of fertilizer system with the basics of ecological agrochemistry. Moscow; Leningrad: M.V. Lomonosov Moscow State University, 320 p.

[3] Mineyev, V.G. (2010). Agrochemistry. Moscow; Leningrad: M.V. Lomonosov Moscow State University, 720 p.

[4] Studentsov, O.V., Petrovskaya, N.N. (1981). Stability of collectible cabbage samples to vascular bacteriosis in the foothill zone of the North Caucasus. Bull VIR, iss. 111, pp. $45--48$. 
[5] Sychev, V.G., Shafran, S.A. (2013). Agrochemical properties of soils and efficiency of mineral fertilizers. Moscow: VNIIA, 296 p.

[6] Anburani., A., Manivannan, K. (2002). Effect of integrated nutrient management on growth in brinjal (Solanum melongena L.) cv. Annamalai. South Indian Horticulture, no. 50 (4--6), pp. 377--386.

[7] Aravind, P., Prasad, M.N.V. (2005). Cadmium-induced toxicity reversal by zinc in Ceratophyllum demersum $L$. (a free floating aquatic macrophyte) together with exogenous supplements of amino and organic acids.

[8] Buczacki, S. (1983). Plasmodiophora -- an interrelationship between biological and practical problems. In Buczacki S. (eds.): Zoosporic plant pathogens -- a modern perspective. London: Academic Press, pp. 161--191.

[9] Calvo, P., Nelson, L., Kloepper, J.W. (2014). Agricultural uses of plant biostimulants. Plant Soil, vol. 383, pp. 3--41.

[10] du Jardin, P. (2005). Ad hoc Study Report to the European Commission DG ENTR. The Science of Plant Biostimulants -- A bibliographic analysis.

[11] Ebaid, R.A., El-Refaee, I.S. (2007). Utilization of rice husk as an organic fertilizer to improve productivity and water use efficiency in rice fields. African Crop Science Conference Proceedings, no. 8, pp. 1923--1928.

[12] Ghasemi, S., Khoshgoftarmanesh, A.H., Hadadzadeh, H., Jafari, M. (2012). Synthesis of iron-amino acid chelates and evaluation of their efficacy as iron source and growth stimulator for tomato in nutrient solution culture. J. Plant Growth. Regul., no. 31(4), pp. 498--508.

[13] Ghasemi, S., Khoshgoftarmanesh, A.H., Afyuni, M., Hadadzadeh, H. (2013a). The effectiveness of foliar applications of synthesized zinc-amino acid chelates in comparison with zinc sulfate to increase yield and grain nutritional quality of wheat. Eur. J. Agron., no. 45, pp. 68--74.

[14] Ghasemi, S., Khoshgoftarmanesh, A.H., Hadadzadeh, H., Afyuni, M. (2013b). Synthesis, characterization, and theoretical and experimental investigations of zinc (II)-amino acid complexes as ecofriendly plant growth promoters and highly bioavailable sources of zinc. J. Plant Growth Regul., no. 32(2), pp. 315--323.

[15] Halpern, M., Bar-Tal, A., Ofek, M., Minz, D., Muller, T., Yermiyahu, U. (2015). The use of biostimulants for enhancing nutrient uptake, ed. D.L. Sparks. Advances in Agronomy, vol. 129, pp. 141--174.

[16] Han, D.-F., Wang, D-H., Huang, P.-Zh., Duan, J-X., Ge, R-Sh., Zhou, W.-L. (2010). Effects of Different Morphology Magnesium on Yield and Quality of Zaoshu 5' Chinese cabbage. Acta Horticulturae Sinica, no. 10. 
[17] Kirkby, E.A., Römheld, V. (2005). International Fertiliser Society. Micronutrients in plant physiology: functions, uptake and mobility (no. 543.

[18] Liu, D-H., Zhao, H.-Y., Zheng, X.-R., Shao, J.-H., Gao, Z-X. (2005). Effect of amino acid chelated microelement fertilizer on yields and qualities of wheat and rice. Journal of Nanjing Agricultural University, no. 02.

[19] Mirza, H.K.U., Ahamed, N.M., Rahmatullah, N., Akhter, K.N., Rahman, M.L. (2010). Plant growth characters and productivity of wetland rice (Oryza sativa L.) as affected by application of different manures. Emir. J. Food Agric., no. 22(1), pp. 46--58.

[20] Oburger, E., Kirk, G.J.D., Wenzel, W.W., Puschenreiter, M., Jones, D. (2009). Interactive effects of organic acids in the rhizosphere. Soil Biol., table 1 (Porochovskii).

[21] Ramesh, P., Singh, M., Subbarao, A. (2005). Organic Farming: Its relevance to the Indian context. Current Science, no. 88, pp. 561--569.

[22] Shao, J., Lu, T.J. (2000). Review of production of amino acid based microelement fertilizer and its application. Phosphate and compound fertilizer, no. 04.

[23] Shomron, N., Malca, H., Vig, I., Ast, G. (2002). Reversible inhibition of the second step of splicing suggests a possible role of zinc in the second step of splicing. Nucleic Acids Res., no. 30, pp. 4127--4137.

[24] Singh, R., Agarwal, S.K. (2000). Analysis of growth and productivity of wheat in relation to levels of FYM and nitrogen. Indian Journal of Plant Physiology, no. 6, pp. 279--283.

[25] Swarup, A., Yaduvanshi, N.P.S. (2000). Effect of Integrated nutrient management on soil properties and yield of rice in Alkali soils. J. Indian Soc. Soil Sci., no. 48, pp. 279--282.

[26] Wójcik, P. (2004). Uptake of mineral nutrients from foliar fertilization (Review). J. Fruit Ornam. Plant Res. Special ed., vol. 12, pp. 201--218.

[27] Xu, W.H., Liu, H., Ma, Q.F., Xiong, Z.T. (2007). Root exudates, rhizosphere Zn fractions, and $Z n$ accumulation of ryegrass at different soil $Z n$ levels.

[28] Yadana, K.L., Aung, K.M., Takeo, Y., Kazuo, O. (2009). The Effects of Green Manure (Sesbania rostrata) on the Growth and Yield of Rice. J. Fac. Agr., Kyushu Univ., no. 54(2), pp. 313--319. 